\title{
Dry matter partitioning and harvest index of maize crop as influenced by integration of sheep manure and urea fertilizer
}

\author{
Sajid Khan ${ }^{1}$, Ahmad Khan ${ }^{1}$, Fazal Jalal ${ }^{2 *}$, Maaz Khan ${ }^{3}$, Haris Khan ${ }^{1}$, \\ Said Badshah ${ }^{1}$ and Sadiq Shah ${ }^{2}$ \\ 1. Department of Agronomy, The University of Agriculture, Peshawar- Pakistan \\ 2. Department of Agriculture Abdul Wali Khan University Mardan-Pakistan \\ 3. Department of Soil \& Environmental Sciences, The University of Agriculture, Peshawar-Pakistan \\ *Correspondence author: jalal_146@yahoo.com \\ Citation \\ Sajid Khan, Ahmad Khan, Fazal Jalal, Maaz Khan, Haris Khan, Said Badshah and Sadiq Shah. Dry matter \\ partitioning and harvest index of maize crop as influenced by integration of sheep manure and urea fertilizer. \\ Pure and Applied Biology. Vol. 6, Issue 4, pp1382-1396. http://dx.doi.org/10.19045/bspab.2017.600149
}

\begin{tabular}{llll}
\hline \hline Received: 20/07/2017 & Revised: 27/10/2017 & Accepted: 28/10/2017 & Online First: 30/10/2017 \\
\hline \hline
\end{tabular}

\section{Abstract}

The experiment was designed to evaluate the effect of sheep manure (SM), its application timing (AT) and $\mathrm{N}$ fertilizer (urea) on dry matter partitioning and harvest index of maize crop. The study was conducted on RCBD split plots arrangement at Agronomic research farm during 2015. The Sheep manure (SM1 $=3 \mathrm{tha}^{-1}, \mathrm{SM} 2=4 \mathrm{t} \mathrm{ha}^{-1}, \mathrm{SM} 3=5 \mathrm{tha}^{-1}$ ) and application timing (AT1 = 15 days before sowing, AT2= at sowing time) were allotted to main plots however, fertilizer $\mathrm{N}\left(\mathrm{N} 1=0 \mathrm{~kg} \mathrm{ha}^{-1}, \mathrm{~N} 2=90 \mathrm{~kg} \mathrm{ha}^{-1}, \mathrm{~N} 3=120 \mathrm{~kg} \mathrm{ha}^{-1}\right)$ were applied to sub-plots. Application of $5 \mathrm{t} \mathrm{ha}^{-1}$ of sheep manure at 15 days before sowing significantly enhanced pre tesseling (stem and leaves) and physiological maturity (stem, leaves, cobs and grains), dry matter partitioning and harvest index. Pre tassel and at physiological maturity dry matter accumulation were higher with application of $120 \mathrm{~kg} \mathrm{~N} \mathrm{ha}^{-1}$. However, application of $5 \mathrm{t}$ sheep manure ha ${ }^{-1}$ at 15 days before sowing and $120 \mathrm{~kg} \mathrm{~N} \mathrm{ha}^{-1}$ is recommended for higher dry matter accumulation of maize crop.

Keywords: Sheep manure; Nitrogen; Application timing; Dry matter; Harvest index

\section{Introduction}

Maize (Zea mays L.) is the third most important crop in the world after wheat and rice. It is a tropical crop but can be grown profitably in subtropical and temperate climatic zones of the world during spring and summer season [1]. In Pakistan after wheat and rice, maize holds the central position and is extensively cultivated (1.11 million hectares) in Punjab and Khyber Pakhtunkhwa [2]. In Pakistan satisfactory potential yield has not been achieved due to several limitations. The poor soil organic matter and imbalance fertilizer application are the important limitations, which limits plants growth, carbohydrate production and dry matter accumulation $[3,4]$.

Dry matter production is basically a measure of plant photosynthetic efficiency [5], which is influenced by balance nutrient availability [6] and environmental factors [7]. Leaves are the major source of dry matter production through photosynthesis and then accumulated into various plant parts through different physiological processes [5]. The dry matter production in 
cereals is highly depended on plant photosynthetic efficiency and the sink capacity to accumulate the photosynthates from the leaf [8]. The balance nutrient provision increase the dry matter production into various plant parts through its impact on more leaf area production and high photosynthetic rates [9]. The dry matter production highly influenced the plant biomass production and grain yield of the crop [10, 11]. Nitrogen is very important for crop plants especially for cereals. Uptake of nitrogen by plant roots occurs in the form of ammonium $\left(\mathrm{NH}^{4+}\right)$ and $\mathrm{NO}^{3-}$ which becomes available through mineralization and nitrification respectively [12]. Nitrogen fertilizer enhances the vegetative growth, maize biomass and dry matter production [13], which ultimately resulted in higher crop productivity [14]. Nitrogen is very important for optimum plant return in term of dry matter and crop yield, but it had also adverse effects on soil fertility, environment and because of its high cost it increase the cost benefit ratio of crop [15]. Combined use of chemical and natural fertilizers is advantageous in enhancing the availability of nitrogen, phosphorus and potassium in plants [16], improve soil fertility and productivity on sustainable basis [17]. These improved soil properties and nutrients availability enhance the fresh and dry biomass production and improve the crop growth [18].

Sheep manure contain high amount of primary macro nutrients and other essential nutrients for plants [19]. The use of organic matter positively influences vegetative and reproductive growth of plants [20] and dry matter production [21]. Naturally available animal manure and plant residues can be used as an alternative cheaper source of synthetic fertilizers [22]. It provide nutrients to plants and adsorb essential nutrients such as $\mathrm{Fe}^{2+}, \mathrm{Mg}^{2+}$ and $\mathrm{NH}^{4+}$ cations, which are essential for enzymes activation and chlorophyll formation, and assimilates production [23]. To get optimum returns from manure application it should be incorporated at proper time, to synchronize the nutrient release from manure with supreme crop growth stage. The better synchronization of nutrients with crop occurs because of rapid mineralization and decomposition at initial stage [24].

Fertilizer is added to soil either in organic or inorganic form for improvement of chemical properties, improving soil fertility, and increase maize production. However, information are limited on the use of sheep manure as a source of organic fertilizers, it application time and also in combination with urea fertilizer. Therefore, this experiment was designed to find out the response of maize dry matter and their respective accumulation into various parts by the integrated use of sheep manure and fertilizer N (urea).

\section{Materials and methods}

An experiment was designed at Agronomy Research Farm, The University of Agriculture Peshawar, to find out the impact of combined application of sheep manure and urea fertilizer. Randomized complete block design with split plot arrangement was used with four replications. Sheep manure at the rate of 3, 4 and $5 \mathrm{tha}^{-1}$ and application timing at two levels ( 15 days before sowing and at sowing time) was allotted to main plots and fertilizer $\mathrm{N}$ at 3 levels $\left(0,90\right.$ and $120 \mathrm{~kg} \mathrm{ha}^{-}$ ${ }^{1}$ ) was allotted to sub plots of size $5 \mathrm{~m} \mathrm{x} 3.5$ $\mathrm{m}$. Sheep manure was incorporated in their respective plots 15 days before sowing and second treatment of SM was applied at sowing time, along with $90 \mathrm{~kg} \mathrm{~N} \mathrm{ha}^{-1}$ (from SSP) and half of fertilizer $\mathrm{N}$ (urea). The second dose of $\mathrm{N}$ was applied at knee height of plant. Azam variety was sown on $19^{\text {th }}$ June 2015 with the help of seed drill. Plant to Plant distance of $20 \mathrm{~cm}$ was maintained after proper thinning. Weed was removed from field with the help of hoeing. The crop was harvested at proper maturity and then sun dried and threshed. Dry matter was calculated at two stages of crop growth that is given below.

Dry matter partitioning was recorded at pre tasseling stage by randomly harvesting $1 \mathrm{~m}$ 
row from each sub plot. Harvested plants were divided into stem and leaves (leaf sheath+ leaf blade), and these materials were oven dried at $70^{\circ} \mathrm{C}$ for 24 hours and their weights were recorded with the help of sensitive balance. At physiological maturity dry matter partitioning was computed by harvesting $1 \mathrm{~m}$ long row selected randomly from each sub plot. The harvested plants were separated into stem, leaf, husk, grains, cobs and tassel. These materials were oven dried at $70^{\circ} \mathrm{C}$ for 24 hours and their weights were recorded.

The data was analyzed statistically with analysis of variance technique appropriate for RCBD split plots arrangement. Means by integrated management of sheep manure and urea fertilizer

\begin{tabular}{|c|c|c|c|}
\hline \multirow{2}{*}{ Treatments } & \multicolumn{2}{|c|}{ DM in plant components $\left(\mathrm{g} \mathrm{plant}^{-1}\right)$} & \multirow{2}{*}{ Total } \\
\hline & Stem & Leaf & \\
\hline \multicolumn{4}{|l|}{ Sheep manure $\left(\mathrm{t} \mathrm{ha}^{-1}\right)$} \\
\hline 3 & $8.9 \mathrm{~b}$ & $21.8 \mathrm{~b}$ & $30.8 \mathrm{~b}$ \\
\hline 4 & $9.9 \mathrm{a}$ & $22.8 \mathrm{ab}$ & $32.7 \mathrm{ab}$ \\
\hline 5 & $10.0 \mathrm{a}$ & $25.5 \mathrm{a}$ & $35.5 \mathrm{a}$ \\
\hline $\mathrm{LSD}_{0.05}$ & 0.4 & 2.7 & 2.7 \\
\hline \multicolumn{4}{|c|}{ Application timing (Days before sowing) } \\
\hline 15 & $9.9 \mathrm{a}$ & $24.6 \mathrm{a}$ & $34.4 \mathrm{a}$ \\
\hline 0 & $9.3 \mathrm{~b}$ & $22.2 \mathrm{~b}$ & $31.5 \mathrm{~b}$ \\
\hline $\mathrm{LSD}_{0.05}$ & 0.3 & 2.2 & 2.2 \\
\hline \multicolumn{4}{|l|}{ Nitrogen $\left(\mathrm{kg} \mathrm{ha}^{-1}\right)$} \\
\hline 0 & $8.7 \mathrm{c}$ & $21.7 \mathrm{~b}$ & $30.4 \mathrm{~b}$ \\
\hline 90 & $9.2 \mathrm{~b}$ & $22.2 \mathrm{~b}$ & $31.5 \mathrm{~b}$ \\
\hline 120 & $10.8 \mathrm{a}$ & $26.3 \mathrm{a}$ & $37.1 \mathrm{a}$ \\
\hline $\mathrm{LSD}_{0.05}$ & 0.4 & 1.6 & 1.6 \\
\hline Interactions & P-value & P-value & P-value \\
\hline SM x AT & 0.098 & 0.140 & 0.230 \\
\hline $\mathrm{SM} \times \mathrm{N}$ & 0.000 & 0.027 & 0.008 \\
\hline AT x SM & 0.832 & 0.386 & 0.356 \\
\hline SM x AT x N & 0.410 & 0.842 & 0.951 \\
\hline
\end{tabular}

$\mathrm{SM}=$ Sheep manure, $\mathrm{AT}=$ Application time, $\mathrm{N}=$ Nitrogen

Means having different alphabets in the same category are statistically different using LSD test at $\mathrm{P} \leq 0.05$

Sheep manure application of $5 \mathrm{t} \mathrm{ha}^{-1}$ amassed maximum stem, leaf and total pre tasselling dry matter $(10,25.5$, and $35.5 \mathrm{~g}$ plant $^{-1}$ ) respectively followed by $4 \mathrm{t} \mathrm{ha}^{-1}$ $\left(9.9,22.8,32.7 \mathrm{~g} \mathrm{plant}^{-1}\right)$ while lowest dry matter $\left(8.9,21.8,30.8 \mathrm{~g}\right.$ plant $\left.^{-1}\right)$ was noticed from plots receiving $3 \mathrm{t} \mathrm{ha}^{-1}$ sheep manure. Dry matter production is a function of nutrients availability and uptake by the were compared by LSD technique at 0.05 level of probability.

Results and discussion

Dry matter partitioning at pre tasselling (g plant ${ }^{-1}$ )

Data regarding dry matter partitioning in stem, leaves and total dry matter (TDM) at pre tasselling is demonstrated in Table 1. Data analysis clarified that stem dry matter was significantly influenced by different sheep manure rates, its application time and $\mathrm{N}$ levels. Among various interactions only $\mathrm{SM} \times \mathrm{N}$ was found to have significant effects for pre tasselling dry matter partitioning. 
increased the photosynthetic efficiency and partitioning of photo assimilates [25]. These findings are fully supported by [26] who concluded that manure incorporation into the soil supply essential nutrients $(\mathrm{N}, \mathrm{P}$, $\mathrm{K}, \mathrm{Ca}, \mathrm{Mg}, \mathrm{Fe}, \mathrm{Cu}, \mathrm{Mn}$ and $\mathrm{Zn}$ ) to the maize crop, that resulted in maximum dry matter production with higher rates of manure. Greater dry matter $\left(9.9,24.6,34.4\right.$ g plant $^{-}$ $\left.{ }^{1}\right)$ was resulted from plots receiving sheep manure 15 days before sowing while its incorporation at planting time accumulated lowest dry matter $\left(9.3,22.2,31.5 \mathrm{~g} \mathrm{plant}^{-1}\right)$ respectively in stem, leaves and whole plant. Maximum dry matter accumulation recorded from plots receiving sheep manure prior to planting could be due to better mineralization of sheep manure and synchronization of nutrient release with crop growth stage, this timely nutrient availability might have increased the crop growth rate, leaf area, and dry matter partitioning in stem and leaves [27].

At pre tasseling highest dry matter in stem, leaves and whole plant $(10.8,26.3,37.1 \mathrm{~g}$ plant $^{-1}$ ) respectively was accumulated by applying $120 \mathrm{~kg} \mathrm{~N} \mathrm{ha}^{-1}$, that was higher than dry matter $\left(9.2,22.2,31.5 \mathrm{~g}\right.$ plant $\left.^{-1}\right)$ accumulated by $90 \mathrm{~kg} \mathrm{~N}$ ha $^{-1}$ treatment, while lowest stem dry matter $(8.7,21.7$, $30.4 \mathrm{~g} \mathrm{plant}^{-1}$ ) was observed in stem, leaves, and whole plant respectively in plots with no nitrogen application. Maximum dry matter accumulation with higher $\mathrm{N}$ level could be explained by the fact that $\mathrm{N}$ fertilization is indispensible for photosynthesis and protein synthesis, and higher photosynthetic efficiency ultimately resulted in maximum dry matter production. These finding are supported and confirmed by [28] who concluded increase in dry matter production with increasing $\mathrm{N}$. Leaf, stem and ultimately total dry matter production in plots receiving $120 \mathrm{~kg} \mathrm{~N} \mathrm{ha}^{-1}$ was probably due to essentiality of nitrogen for protein synthesis, amino acids, enzymes, coenzymes, nucleic acids, phytochromes, and chlorophyll formation, that have the effects on dry matter production [29], high chlorophyll content, photosynthesis and photo assimilates [25].

Interaction $\mathrm{SM} \times \mathrm{N}$ (Figure 1) reveals that increasing sheep manure rates from 3 to $4 \mathrm{t}$ $\mathrm{ha}^{-1}$, stem dry matter production was not significantly affected with enhancing $\mathrm{N}$ levels, from 0 and $90 \mathrm{~kg} \mathrm{ha}^{-1}$, however it increased significantly with $120 \mathrm{~kg} \mathrm{~N} \mathrm{ha}^{-1}$, but with application of $5 \mathrm{t} \mathrm{SM} \mathrm{ha}{ }^{-1}$ it increased linearly across all the three levels of $\mathrm{N}$. The SM x N interaction (Figure 2) indicated that in plots having 3 and $4 \mathrm{t} \mathrm{SM}$ $\mathrm{ha}^{-1}$, the leaf dry matter production increased slightly with nitrogen rates from 0 and $90 \mathrm{~kg} \mathrm{ha}^{-1}$, however leaf dry matter greatly decreased with $5 \mathrm{t} \mathrm{SM} \mathrm{ha}{ }^{-1}$, and was further increased with increasing $\mathrm{N}$ from 90 to $120 \mathrm{~kg} \mathrm{ha}^{-1}$. The relative increase in leaf dry matter was highly pronounced in $5 \mathrm{t} \mathrm{SM}$ ha $^{-1}$ treated plots. SM $\mathrm{x} N$ interaction (Figure 3) reveals a mild increase in TDM from 3 and $4 \mathrm{t} \mathrm{SM} \mathrm{ha-1}$ with increasing $\mathrm{N}$ levels from 0 to $90 \mathrm{~kg} \mathrm{ha}^{-1}$ resulted in nonsignificant differences. In $5 \mathrm{t} \mathrm{ha}^{-1}$ sheep manure treated plots TDM accumulation first decrease with nitrogen levels from 0 to $90 \mathrm{~kg} \mathrm{ha}^{-1}$, whereas more increase in $\mathrm{N}$ enhanced total dry matter accumulation in maize.

Highest dry matter at pre tasselling with combined application of SM and urea fertilizer could be related to the balanced nutrients provision, improved soil physical and chemical properties, and higher $\mathrm{N}$ that might have improved plant metabolism, photosynthetic efficiency, leaf expansion and plant growth and might have increased the dry matter production $[6,29]$ observed maximum DM accumulation from combined use of manure and synthetic fertilizer which was in conformity to our finding. The maximum dry matter production by leaves compared to stem was in negation with the finding of [30] who observed maximum dry matter accumulation in stem compared to leaves after 8 weeks of sowing the crop. Dry matter accumulated in leaves up to leaf area index of 5 , thereafter further increases in dry matter translocated in to stem [7]. 


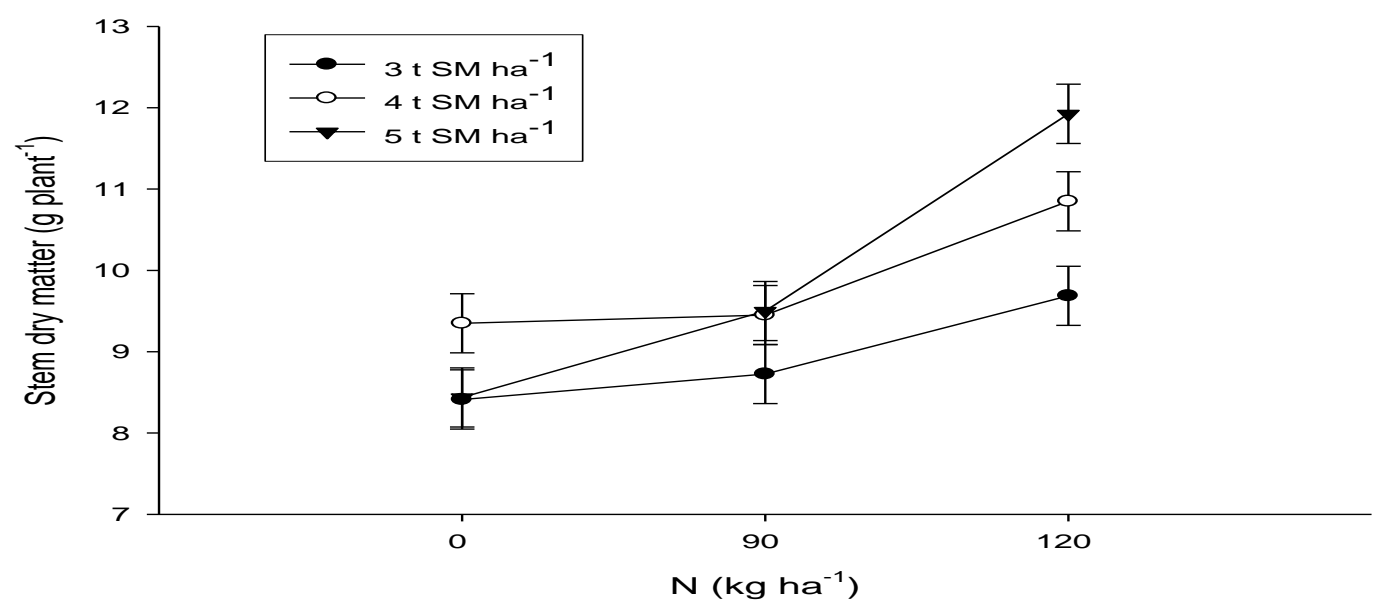

Figure 1. Interactive response of sheep manure (SM) and nitrogen (N) for stem dry matter at pre tasselling

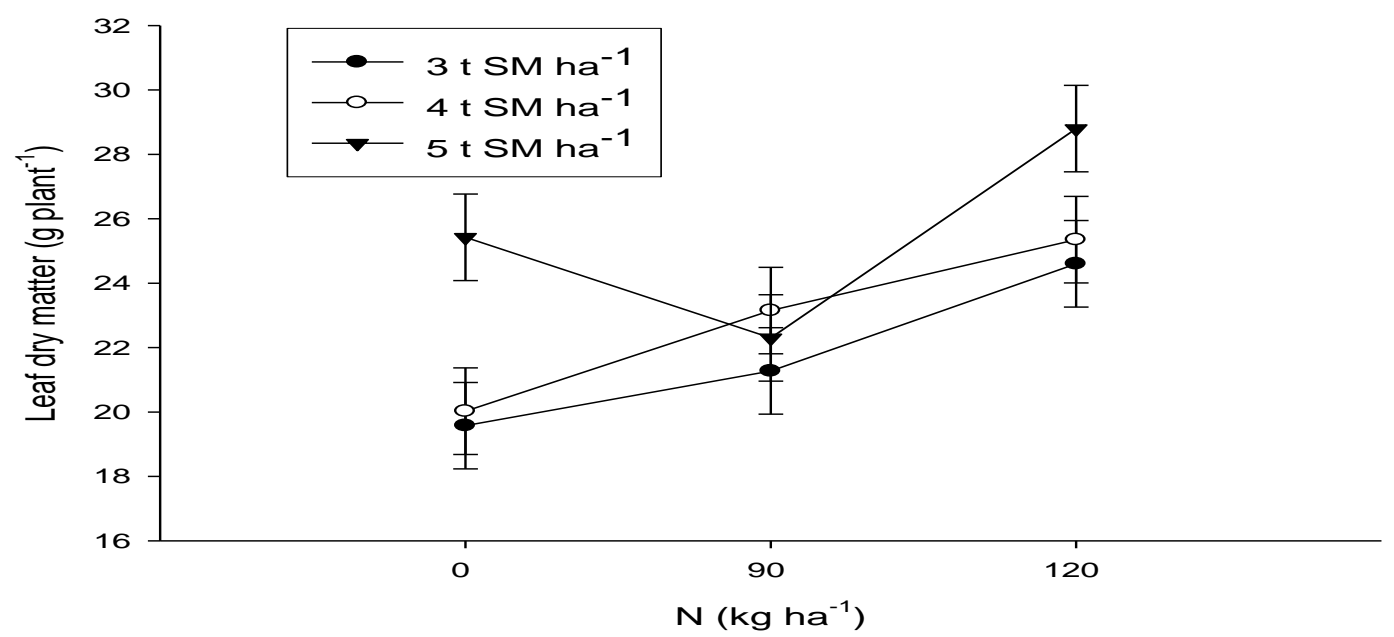

Figure 2. Interactive response of sheep manure (SM) and nitrogen (N) for leaf dry matter at pre tasselling

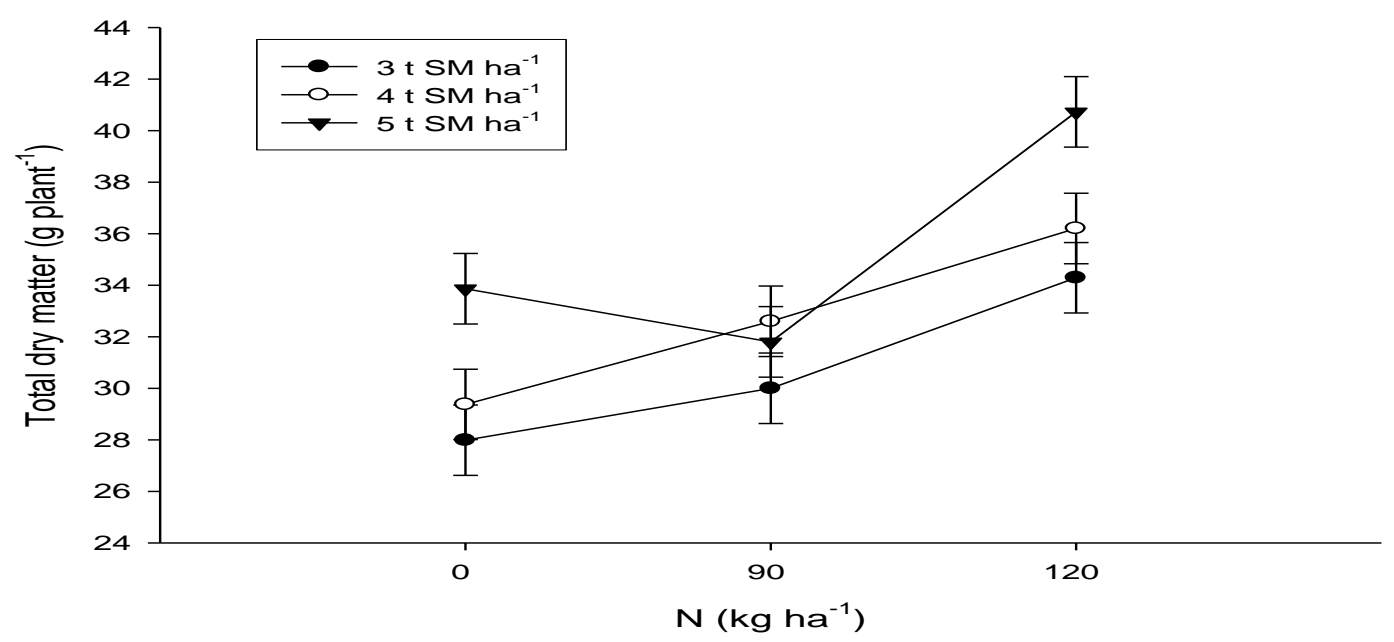

Figure 3. Interactive response of sheep manure (SM) and nitrogen (N) for total dry matter at pre tasselling 
Dry matter portioning at physiological maturity ( g plant $^{-1}$ )

Perusal of the data (Table 2) showed that dry matter (DM) assimilation at physiological maturity stages into different plant components (stem, leaf, cob, grains) was significantly affected by sheep manure, its application timing, nitrogen levels, and $\mathrm{M} \times \mathrm{N}$ interaction, while the remaining interactions except AT x M for grains and total dry matter was found non-significant. Regarding remaining plant (husk and tassel) parts only dry matter accumulation in husk was significantly affected by $\mathrm{N}$ levels, while dry matter partitioning to shank, silk and tassel was found nonsignificant at all levels of sheep manure, its application time and nitrogen rates.

Table 2. Dry matter partitioning (g plant $\left.{ }^{-1}\right)$ at physiological maturity of maize as affected by integrated management of sheep manure and urea fertilizer

\begin{tabular}{|c|c|c|c|c|c|c|c|}
\hline \multirow{2}{*}{ Treatments } & \multicolumn{7}{|c|}{ DM in plant components $\left(\mathrm{g} \mathrm{plant}^{-1}\right)$} \\
\hline & Stem & Leaf & Husk & Cob & Grains & Tassel & Total \\
\hline \multicolumn{8}{|l|}{ SM $\left(\right.$ t ha $\left.^{-1}\right)$} \\
\hline 3 & $34.5 b$ & $30.7 b$ & 12.0 & $9.4 b$ & $49.9 b$ & 3.7 & $151.0 \mathrm{c}$ \\
\hline 4 & $36.3 b$ & $31.6 \mathrm{ab}$ & 11.3 & $10.1 \mathrm{~b}$ & $53.5 b$ & 3.7 & $168.0 \mathrm{~b}$ \\
\hline 5 & $40.3 \mathrm{a}$ & $33.6 \mathrm{a}$ & 11.5 & $11.4 \mathrm{a}$ & $60.2 \mathrm{a}$ & 4.2 & $176.9 \mathrm{a}$ \\
\hline $\mathrm{LSD}_{0.05}$ & 2.9 & 2.11 & N.S & 1.22 & 5.13 & N.S & 8.81 \\
\hline \multicolumn{8}{|c|}{ AT (days before sowing) } \\
\hline 15 & $38.5 \mathrm{a}$ & $32.9 \mathrm{a}$ & 11.8 & $10.8 \mathrm{a}$ & $56.8 \mathrm{a}$ & 4.0 & $169.6 \mathrm{a}$ \\
\hline 0 & $35.5 b$ & $31.1 \mathrm{~b}$ & 11.4 & $9.8 \mathrm{~b}$ & $52.3 \mathrm{~b}$ & 3.8 & $161.0 \mathrm{~b}$ \\
\hline $\mathrm{LSD}_{0.05}$ & 2.3 & 1.72 & N.S & 0.99 & 4.19 & N.S & 7.19 \\
\hline \multicolumn{4}{|l|}{$\mathbf{N}\left(\mathrm{kg} \mathrm{ha}^{-1}\right)$} & \multicolumn{4}{|l|}{ 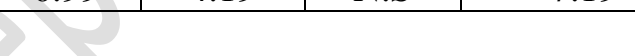 } \\
\hline 0 & $33.2 \mathrm{c}$ & $29.7 \mathrm{c}$ & $9.9 \mathrm{c}$ & $8.7 \mathrm{c}$ & $48.1 \mathrm{c}$ & 3.7 & $150.6 \mathrm{c}$ \\
\hline 90 & $37.1 \mathrm{~b}$ & $32.0 \mathrm{~b}$ & $11.7 \mathrm{~b}$ & $10.2 \mathrm{~b}$ & $54.0 \mathrm{~b}$ & 4.0 & $161.6 \mathrm{~b}$ \\
\hline 120 & $40.8 \mathrm{a}$ & $34.3 \mathrm{a}$ & $13.2 \mathrm{a}$ & $12.0 \mathrm{a}$ & $61.6 \mathrm{a}$ & 4.0 & $183.7 \mathrm{a}$ \\
\hline $\mathrm{LSD}_{0.05}$ & 3.0 & 1.63 & 1.22 & 1.14 & 4.80 & N.S & 6.63 \\
\hline \multicolumn{3}{|c|}{ Interactions $P$ value } & \multicolumn{5}{|l|}{$(5)$} \\
\hline $\mathrm{SM} \times \mathrm{AT}$ & 0.488 & 0.172 & 0.225 & 0.972 & 0.00 & 0.257 & 0.02 \\
\hline SM x N & 0.036 & 0.006 & 0.820 & 0.018 & 0.02 & 0.539 & 0.01 \\
\hline AT $x \mathrm{~N}$ & 0.072 & 0.580 & 0.152 & 0.060 & 0.95 & 0.800 & 0.22 \\
\hline SM x AT x N & 0.064 & 0.219 & 0.722 & 0.063 & 0.71 & 0.987 & 0.57 \\
\hline
\end{tabular}

$\mathrm{SM}=$ Sheep manure, AT= Application time, $\mathrm{N}=$ Nitrogen

Means bearing similar letter(s) are statistically comparable within the same category using LSD test at $\mathrm{P} \leq 0.05$

Mean comparison indicated that maximum dry matter $(40.3,33.6,11.4$, and 60.2, 176.9 $\mathrm{g} \mathrm{plant}^{-1}$ ) were partitioned in to stem, leaf, cob, ear, and whole plant respectively, in plot having $5 \mathrm{t} \mathrm{SM} \mathrm{ha}^{-1}$, which was followed by $4 \mathrm{t} \mathrm{ha}^{-1}(36.3,31.6,10.1,53.5,168.0 \mathrm{~g}$ DM plant $\left.{ }^{-1}\right)$, while lowest dry matter accumulation $(34.5,30.7,9.4,49.9,151.0 \mathrm{~g}$ plant $^{-1}$ ), respectively was reckoned from $3 \mathrm{t}$ $\mathrm{ha}^{-1}$ sheep manure incorporation. Incorporation of 3 and $4 \mathrm{tha}^{-1}$ sheep manure to plants accumulated statistically comparable dry matter at physiological maturity stage across stem, cobs, grains and TDM. In stem more DM accumulation was observed than leaves at physiological maturity. Increased dry matter production from higher levels of sheep manure might be associated with more nutrients availability with higher amounts of sheep manure [19], improved soil aeration, water holding capacity, improved adsorption of calcium, magnesium, and potassium by forming clay humic complexes, and activities of soil microorganism [31], that might have improved plant growth [32], photosynthetic production [25] and accumulated maximum dry matter. These finding are supported by [33] who observed higher dry matter production with 
increasing levels of manure. Likewise with sheep manure incorporation 15 days before sowing higher dry matter was accumulated in stem, leaves, cobs, grains, and in whole plant $\left(38.5,32.9,10.8,56.8,169.6\right.$ g plant $\left.^{-1}\right)$ than its application at sowing time (35.5, $31.1, \quad 9.8, \quad 52.3, \quad 161.0 \mathrm{~g} \quad$ plant $\left.^{-1}\right)$, respectively. This greater production of dry matter with sheep manure application before planting might be due to optimum mineralization of manure, and with more nutrients availability which might have helped in increasing root growth, water use efficiency and better soil fertility [34].

Nitrogen application of $120 \mathrm{~kg} \mathrm{ha}{ }^{-1}$ reckoned optimum dry matter at physiological maturity in stem, leaves, cobs, grains and whole plant $(40.8,34.3,12$, 61.6, $183.7 \mathrm{~g} \mathrm{plant}^{-1}$ ), which was higher than $90 \mathrm{~kg} \mathrm{ha}^{-1} \mathrm{~N}(37.1,32.0,10.2,54$, $161.6 \mathrm{~g} \mathrm{plant}^{-1}$ ), while lowest dry matter (32.2, 29.7, 8.7, 48.1, 150.6 g plant $\left.^{-1}\right)$ was observed from control plots, respectively. Regarding husk optimum dry matter (13.2 $\mathrm{g}$ plant $^{-1}$ ) at physiological maturity was accumulated in plots receiving $120 \mathrm{~kg} \mathrm{~N}^{-} \mathrm{ha}^{-}$ ${ }^{1}$, which was followed by $90 \mathrm{~kg} \mathrm{~N} \mathrm{ha}^{-1}(11.7$ g plant $\left.{ }^{-1}\right)$, while lowest (9.9 $\mathrm{g} \mathrm{plant}^{-1}$ ) was observed from control. Maximum stem, leaves, cobs, grains, husk and total dry matter accumulation with higher rates of nitrogen might have the fact of its influence on vegetative growth of the plant, photosynthesis. These results are in accordance with the finding of $[34,35]$, who observed maximum dry matter production with increasing levels of inorganic fertilizer.

The data in Figure 4 (SM x N) showed no significant increase in stem dry matter accumulation with increasing $\mathrm{N}$ from 0 to $120 \mathrm{~kg} \mathrm{~N} \mathrm{ha}^{-1}$, at $3 \mathrm{t} \mathrm{SM} \mathrm{ha}{ }^{-1}$. With changing $\mathrm{N}$ from 0 to $90 \mathrm{~kg} \mathrm{ha}^{-1}$, plots having $4 \mathrm{t} \mathrm{SM}$ ha $^{-1}$ showed non-significant effect on dry matter accumulation, but higher sheep manure showed a marked increase with increase in $\mathrm{N}$ to $120 \mathrm{~kg} \mathrm{ha}^{-1}$. A strong increase was shown by $4 \mathrm{t} \mathrm{ha}^{-1}$ sheep manure with increasing $\mathrm{N}$ up to 120 over 5 tons $\mathrm{SM} \mathrm{ha}{ }^{-1}$. From SM x N interaction
(Figure 5) it is evident that with increase in $\mathrm{N}$ from 0 to $120 \mathrm{~kg} \mathrm{ha}^{-1}$, No apparent differences for leaf dry matter accumulation in plots having $5 \mathrm{t} \mathrm{SM} \mathrm{ha}{ }^{-1}$ were observed. However, with 3 and $4 \mathrm{t}$ SM ha ${ }^{-1}$ the response was opposite, mean with increase in $\mathrm{N}$ increase in leaf dry matter was observed up to $90 \mathrm{~kg} \mathrm{~N} \mathrm{ha-1}$, and with further increased the leaf dry matter accumulation was decreased. The interaction SM x N (Figure 6) showed that nitrogen increase from 0 to $90 \mathrm{~kg} \mathrm{ha}^{-1}$ dry matter accumulation in cob increased across all the three levels of sheep manure, however with $3 \mathrm{t} \mathrm{ha}^{-1}$ sheep manure the increase was highest, and slighter with other two levels of sheep manure. The AT x $M$ interaction (Figure 7) demonstrated that increasing SM incorporation from 3 to $4 \mathrm{t} \mathrm{ha}^{-1}$ no differences for grains dry matter partitioning were observed with its incorporation in plots at the time of sowing compared to increased grain DM when SM was applied 15 days before sowing. The further increasing sheep manure to $5 \mathrm{t} \mathrm{ha}^{-}$ ${ }^{1}$ non significantly differences for grains dry matter were observed whether it was used at the time of sowing or before sowing. The SM x N interaction (Figure 8) illustrated a linear increase in grains dry matter accumulation in $4 \mathrm{t} \mathrm{ha}^{-1}$ sheep manure treatment from 0 through 90 to $120 \mathrm{~kg} \mathrm{~N}^{-}$ ${ }^{1}$. While in plots received $3 \mathrm{tha}^{-1}$ grains dry matter increased but slightly decreased in 5 $\mathrm{t} \mathrm{ha}{ }^{-1}$ at nitrogen levels of 0 and $90 \mathrm{~kg} \mathrm{ha}^{-1}$, beyond $90 \mathrm{~kg} \mathrm{ha}^{-1}$ increase in $\mathrm{N}$ to $120 \mathrm{~kg}$ $\mathrm{ha}^{-1}$ it significantly enhanced in $5 \mathrm{t} \mathrm{ha}^{-1}$ sheep manure but remain constant in $3 \mathrm{tha}^{-}$ 1. The AT x SM interaction (Figure 9) clearly pointed out that sheep manure application 15 days before planting had significantly increased total dry matter production across all the three sheep manure levels, however the increase with 5 $\mathrm{t}$ ha $^{-1}$ sheep manure was higher than both 3 and $4 \mathrm{t} \mathrm{SM} \mathrm{ha}{ }^{-1}$. Likewise sheep manure incorporation at the sowing time highly enhanced total dry matter accumulation of plants in $5 \mathrm{t} \mathrm{SM} \mathrm{ha}^{-1}$ over sheep manure levels of 3 and $4 \mathrm{tha}^{-1}$. The SM $\mathrm{x} \mathrm{N}$ 
interaction (Figure 10) revealed that total dry matter accumulation increased with $\mathrm{N}$ incorporation from 0 to $120 \mathrm{~kg} \mathrm{ha}^{-1}$ across 4 and $5 \mathrm{t} \mathrm{SM} \mathrm{ha}^{-1}$, however this increase was small from 0 to $90 \mathrm{~kg} \mathrm{ha}^{-1}$, and from onward this point the increase was higher. In case of $3 \mathrm{tha}^{-1}$ sheep manure total dry matter increased with $\mathrm{N}$ application from 0 to 90 , and with no differences thereafter up to 120 $\mathrm{kg} \mathrm{N}$ ha $^{-1}$. Higher dry matter production with combined use of sheep manure and urea fertilizer might be due to more leaf area and LAI by these plants, optimum LAI is an indication of better photosynthesis and more assimilates production [26]. These results are in line with $[5,6,33,34]$.

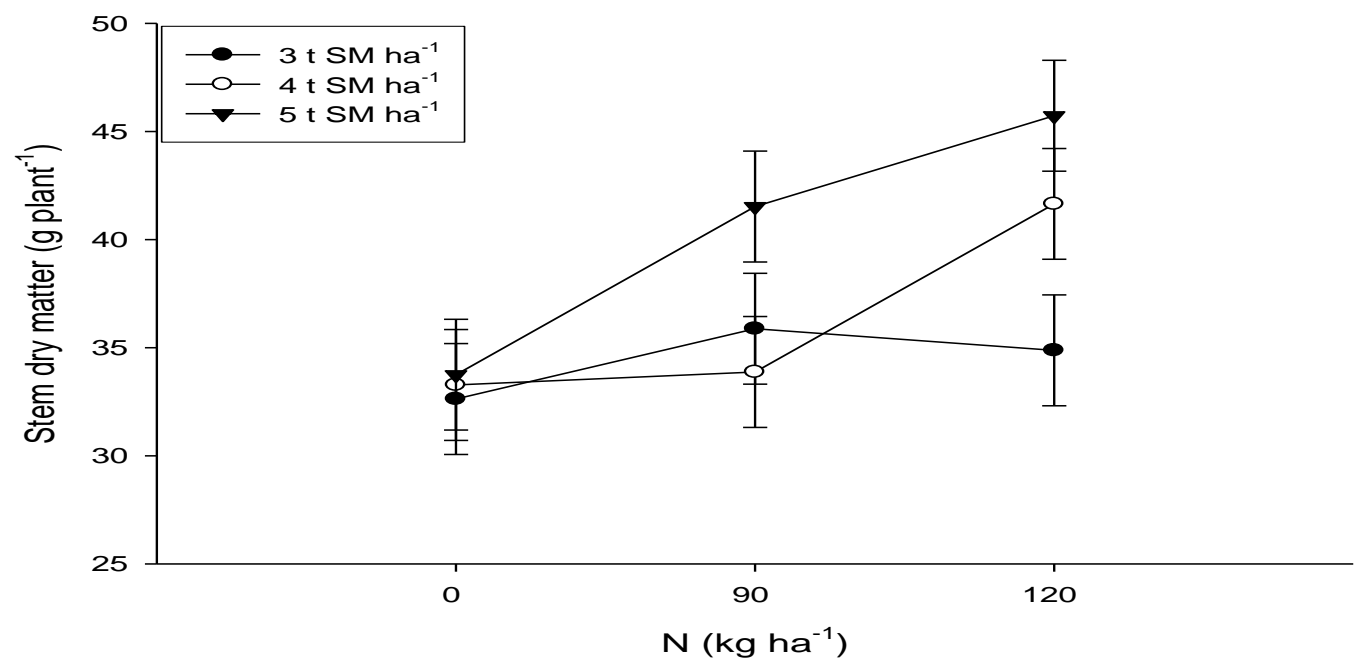

Figure 4. Sheep manure $(\mathrm{SM})$ and nitrogen $(\mathrm{N})$ interactive response for stem dry matter $\left(\right.$ g plant $^{-1}$ ) at physiological maturity

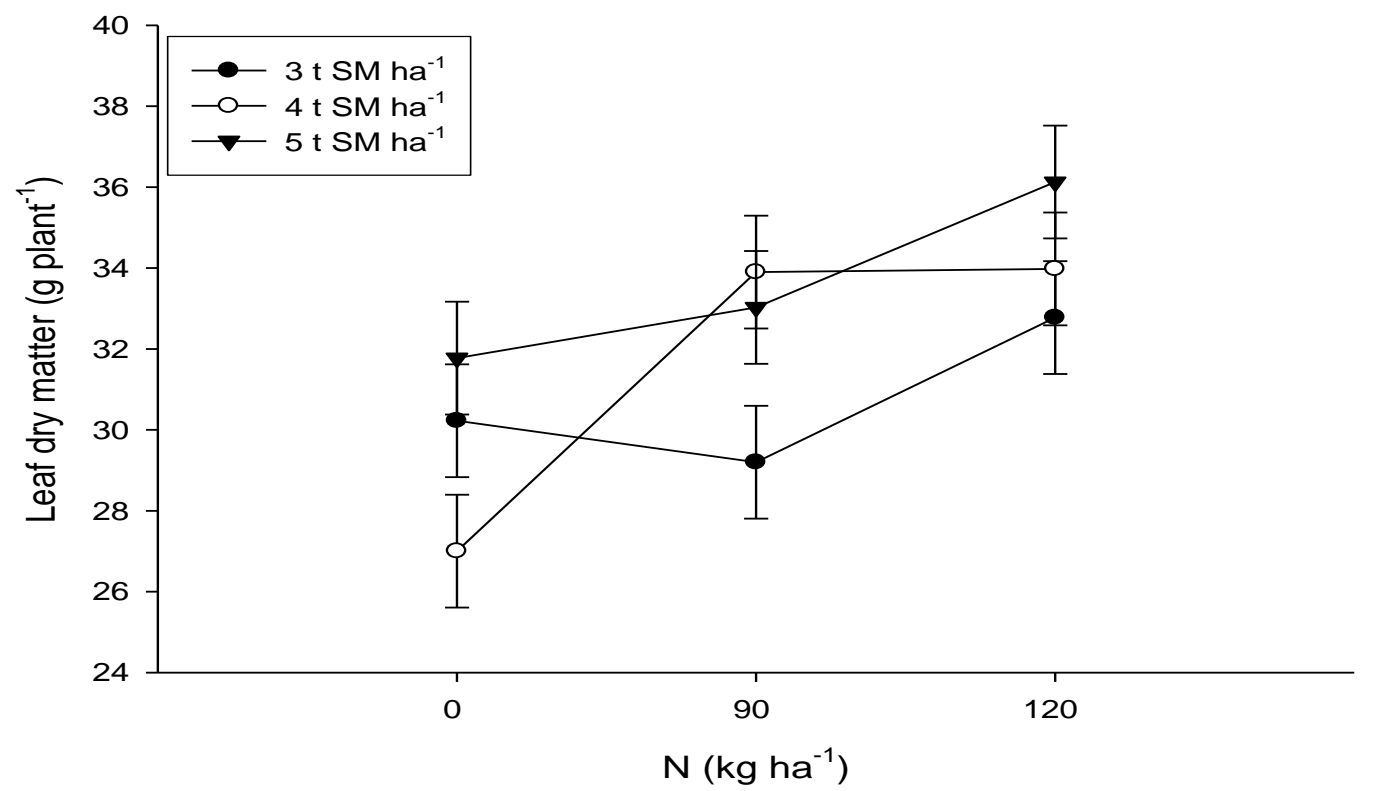

Figure 5. Sheep manure (SM) and nitrogen $(\mathrm{N})$ interaction for leaf dry matter at physiological maturity 


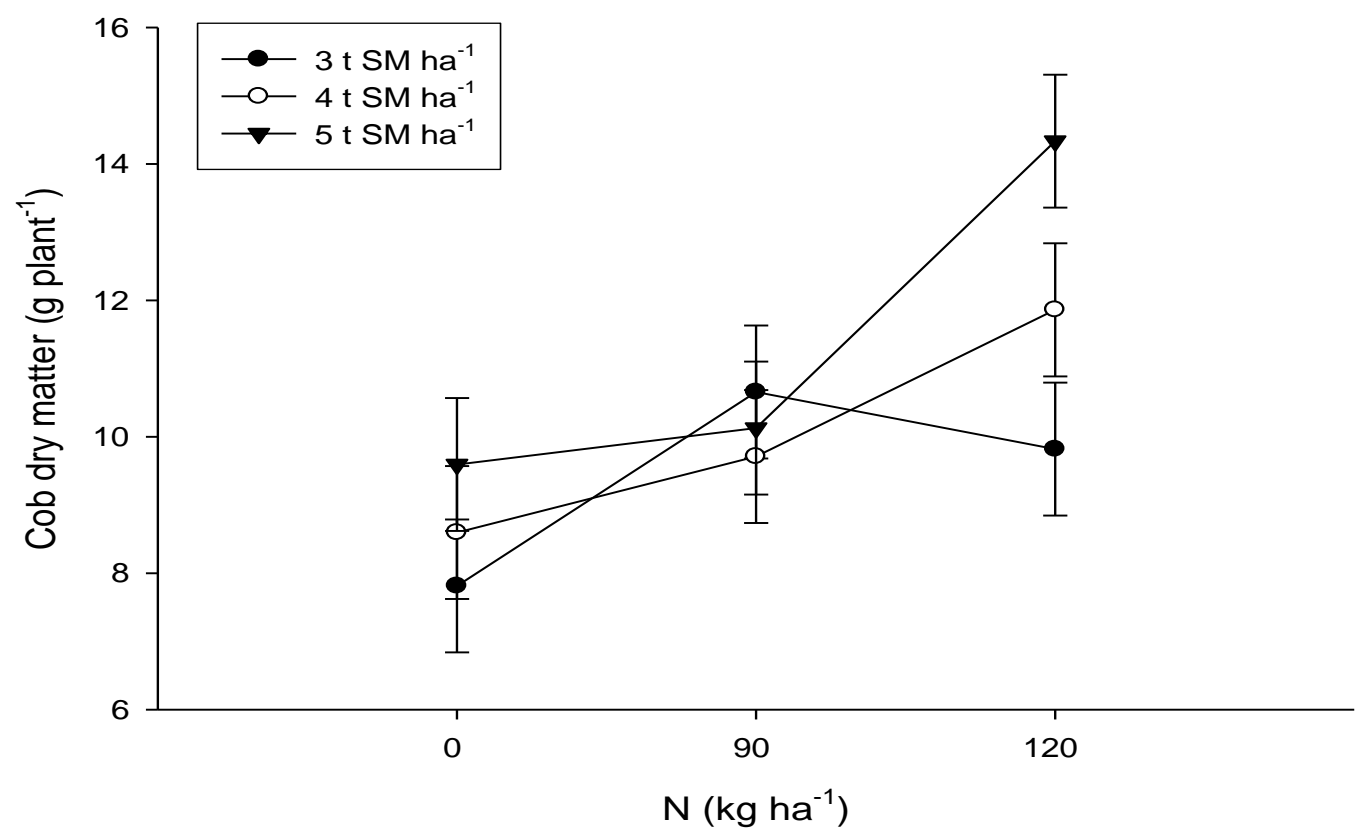

Figure 6. Interactive response of sheep manure (SM) and nitrogen $(\mathrm{N})$ for cob dry matter $\left(g_{\text { plant }}{ }^{-1}\right)$

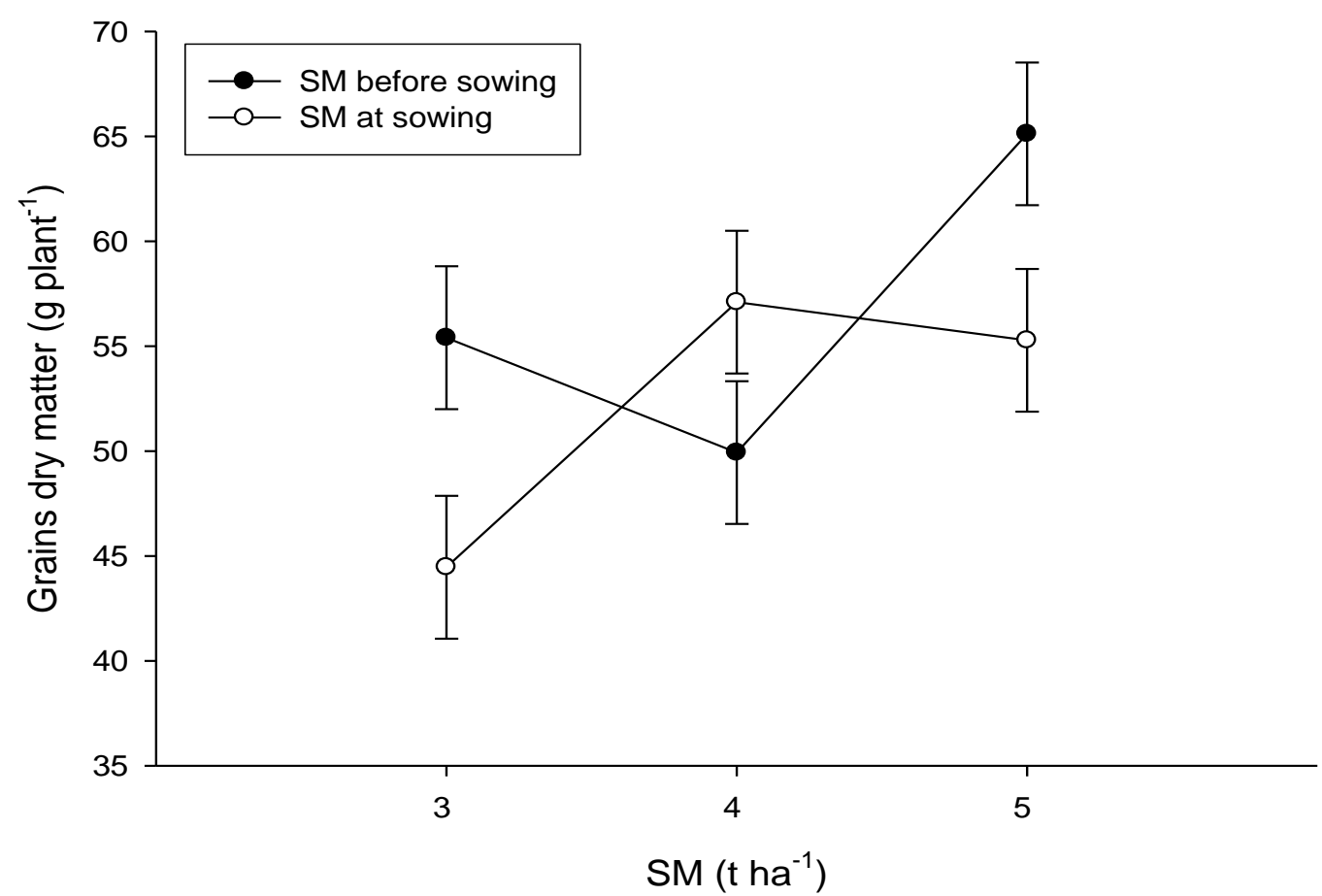

Figure 7. Interactive response of sheep manure (SM) and nitrogen $(\mathrm{N})$ for grains dry matter (g plant $\left.{ }^{-1}\right)$ 
Khan et al.

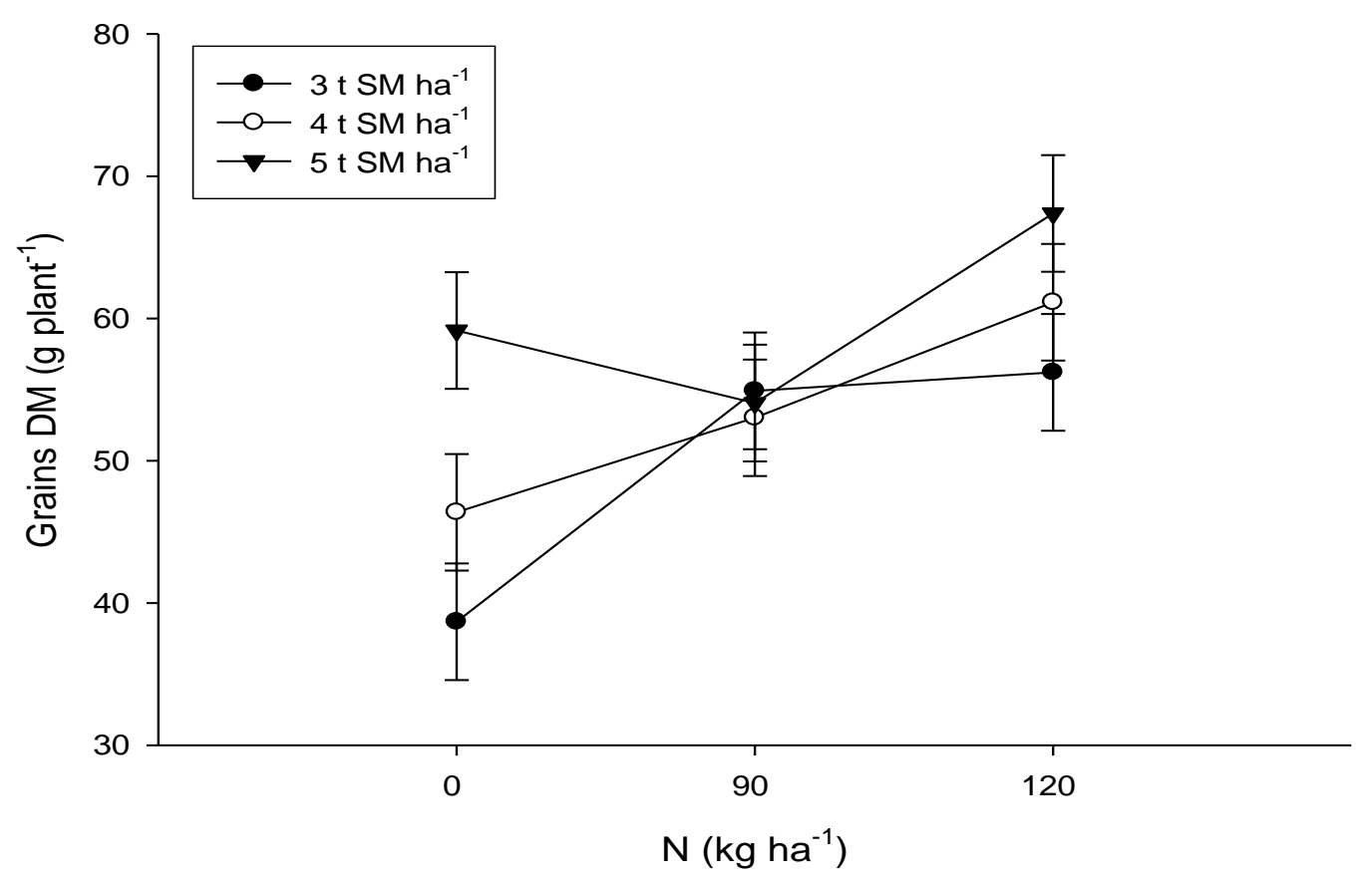

Figure 8. Sheep manure (SM) and nitrogen (N) interactive response for grain dry matter ( g plant $\left.^{-1}\right)$

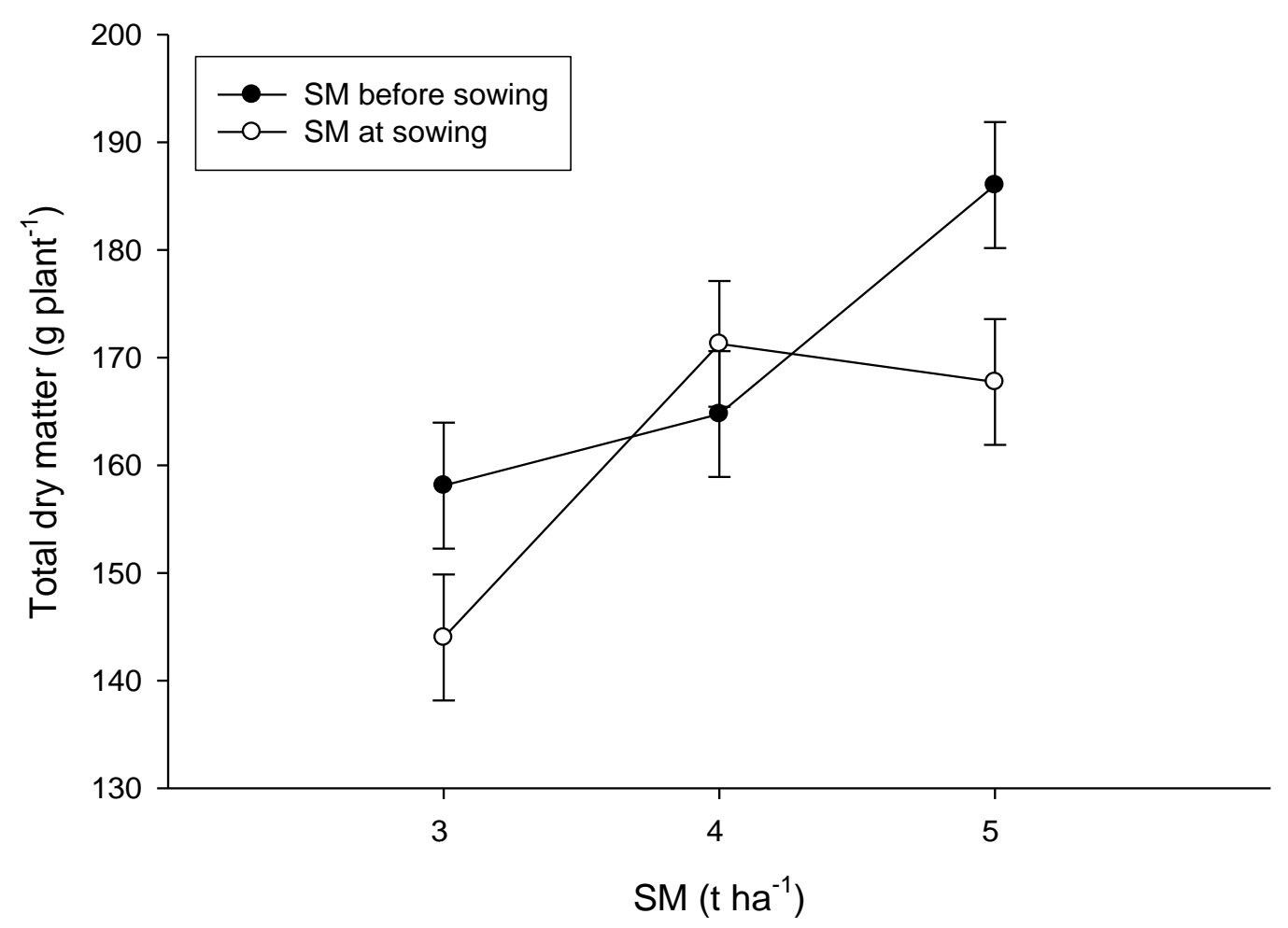

Figure 9. Interactive response of sheep manure (SM) and application time (AT) for total dry matter (g plant $\left.{ }^{-1}\right)$ 


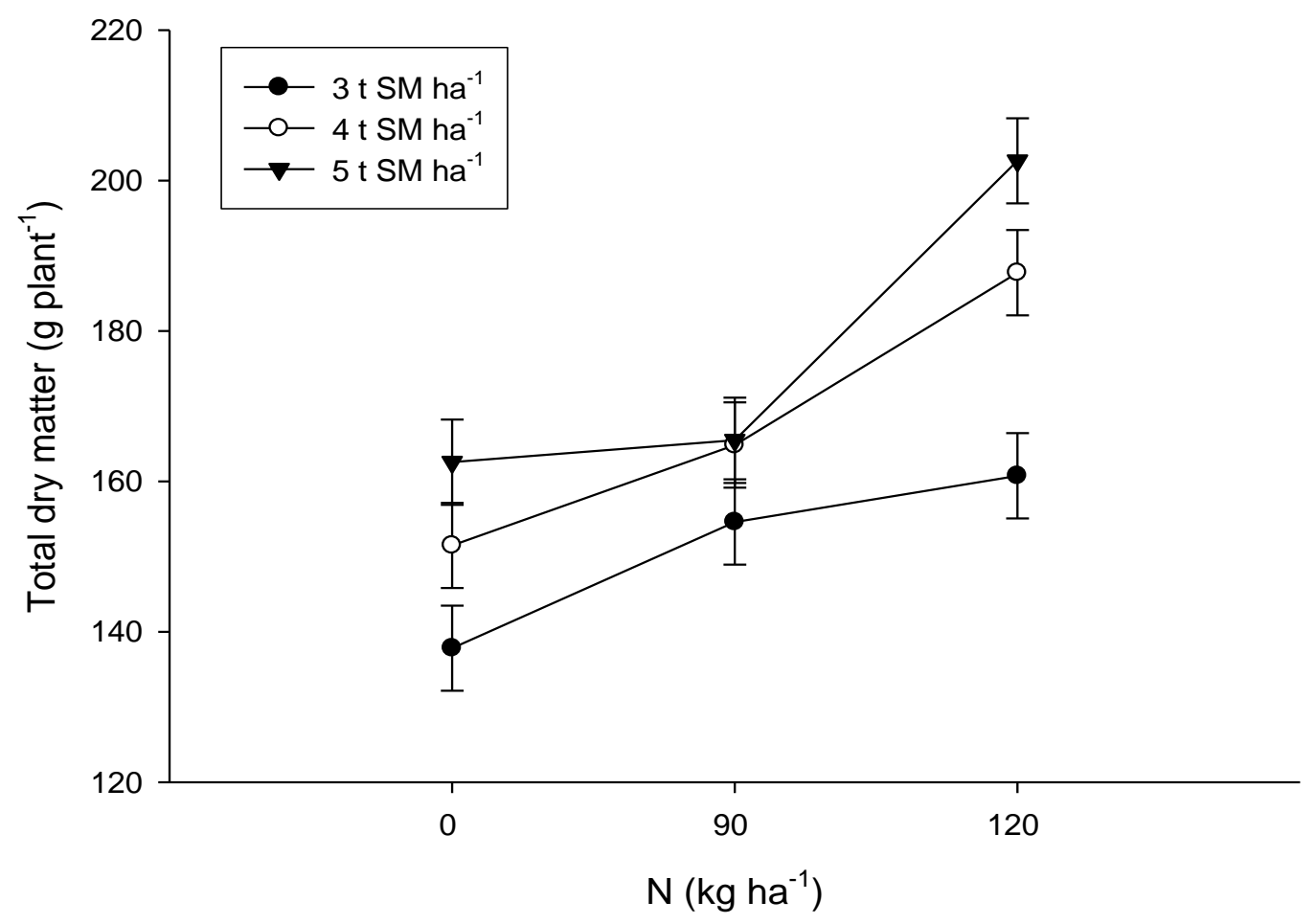

Figure 10. Interactive response of sheep manure (SM) and nitrogen $(\mathrm{N})$ for total $\mathrm{DM}(\mathrm{g}$ plant $^{-1}$ )

Data analysis showed that (Table 3) harvest index was significantly affected by SM, nitrogen levels, AT x SM and SM x N interaction, while application time of SM, and the interactions AT x N and M x AT x $\mathrm{N}$ were found non-significant for Harvest index. SM applied at the rate of $5 \mathrm{t} \mathrm{ha}^{-}$ ${ }^{1}$ resulted maximum harvest index $(35.8 \%)$, followed by $4 \mathrm{t} \mathrm{ha}^{-1}(33.6 \%)$ when compared to the minimum harvest index $(31.9 \%)$ recorded from $3 \mathrm{t}$ SM ha- The physiological efficiency of crop plants in converting photosynthetic products into grain yield is termed as harvest index [36]. Higher harvest index were recorded from sheep manure incremental levels. This increased harvest index with higher sheep manure levels could be associated with enhanced soil cation exchange capacity, increased $\mathrm{C}, \mathrm{N}$, and $\mathrm{P}$ content, and lowered hydraulic conductivity of soil [37], that might had improved photosynthetic efficiency [38] and enhanced assimilates translocation to economic portion [39], which all have direct effects on grain yield, that might have resulted in higher harvest index. This conclusion was supported by [2]. Maximum harvest index $(36.1 \%)$ was recorded from $120 \mathrm{~kg} \mathrm{ha}{ }^{-1}$ nitrogen application, followed by $90 \mathrm{~kg} \mathrm{~N} \mathrm{ha}{ }^{-1}$ $(33.6 \%)$ over the minimum (31.6\%) observed from control. The increased harvest index with higher levels of $\mathrm{N}$ might be due to efficient portioning of assimilates towards the economic portion. These results are in line with [40] who recorded optimum harvest index from higher $\mathrm{N}$ levels. The harvest index further boost up with the integrated use of sheep manure and urea fertilizer. Report of [41] supported our finding. The interaction AT x M (Figure 11) indicated that harvest index was greater in plots having low SM (3 t SM ha-1) when applied before sowing, however, it was greater in plots having greater SM (5 t SM $\mathrm{ha}^{-1}$ ) when soil incorporated at the time of sowing. The SM x N interaction (Figure 12) revealed that increasing $\mathrm{N}$ from 0 to $120 \mathrm{~kg}$ $\mathrm{ha}^{-1}$ had significantly increased harvest index (\%) in plots having $3 \mathrm{t} \mathrm{SM} \mathrm{ha}{ }^{-1}$. However, no significant increases in harvest index were observed with 
increasing $\mathrm{N}$ in plots having higher $\mathrm{SM}$ incorporation (4 to $5 \mathrm{t} \mathrm{ha}^{-1}$ ). Higher harvest index recorded from SM application prior to planting, might be due to more nutrient uptake and higher dry matter portioning toward grain.

Table 3. Harvest index (\%) of maize as influenced by sheep manure and urea fertilizer

\begin{tabular}{|c|c|c|c|c|c|}
\hline \multirow[t]{2}{*}{$\begin{array}{l}\text { Sheep manure } \\
\left(\mathrm{SM}, \mathrm{t} \mathbf{h a}^{-1}\right)\end{array}$} & \multirow{2}{*}{$\begin{array}{l}\text { Application } \\
\text { time of SM } \\
(\mathrm{AT}, \text { days })^{\dagger}\end{array}$} & \multicolumn{3}{|c|}{ Nitrogen rates $\left(\mathrm{N}, \mathrm{kg} \mathrm{ha}^{-1}\right)$} & \multirow[t]{2}{*}{ SM $\times$ AT } \\
\hline & & 0 & 90 & 120 & \\
\hline 3 & \multirow[t]{3}{*}{15} & 26.2 & 36.3 & 39.3 & 33.9 \\
\hline 4 & & 27.9 & 33.4 & 35.2 & 32.2 \\
\hline 5 & & 38.6 & 34.5 & 38.9 & 37.3 \\
\hline 3 & \multirow[t]{3}{*}{0} & 27.3 & 33.2 & 29.3 & 29.9 \\
\hline 4 & & 35.7 & 31.4 & 37.8 & 34.9 \\
\hline \multirow[t]{3}{*}{5} & & 33.7 & 32.6 & 36.4 & 34.2 \\
\hline & 15 & 30.9 & 34.7 & 37.8 & 34.5 \\
\hline & 0 & 32.2 & 32.4 & 34.5 & 33.0 \\
\hline 3 & & 26.7 & 34.8 & 34.3 & $31.9 b$ \\
\hline 4 & & 31.8 & 32.4 & 36.5 & $33.6 \mathrm{ab}$ \\
\hline 5 & & 36.2 & 33.5 & 37.7 & $35.8 \mathrm{a}$ \\
\hline Mean & & 31.6 & $33.6 \mathrm{ab}$ & $36.1 \mathrm{a}$ & \\
\hline
\end{tabular}

†SM application was made 15 or 0 days before sowing

\begin{tabular}{|c|c|c|c|}
\hline Interactions & $\underline{\text { P-values }}$ & $\underline{\text { Interactions }}$ & $\underline{\text { P-values }}$ \\
\hline SM x AT & 0.053 & AT x N & 0.191 \\
\hline SM x N & 0.033 & SM x AT x N & 0.131 \\
\hline LSD $_{0.05}$ for SM and AT & $2.93, \quad$ NS & LSD 0.05 for N & 2.68 \\
\hline
\end{tabular}

Means bearing identical letter(s) in the same column are comparable using LSD test at $\mathrm{P} \leq 0.05$

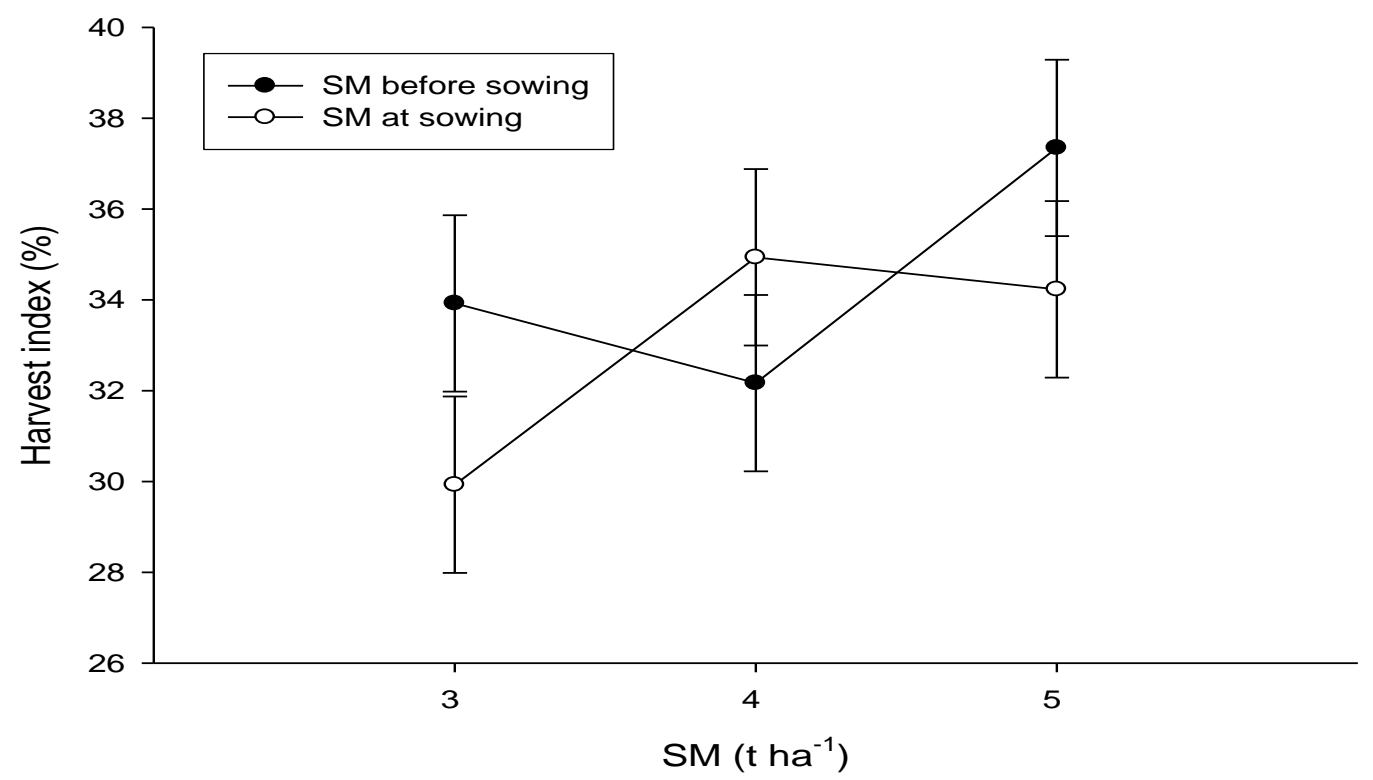

Figure 11. Interactive response of sheep manure (SM) and application time (AT) for harvest index $(\%)$ 


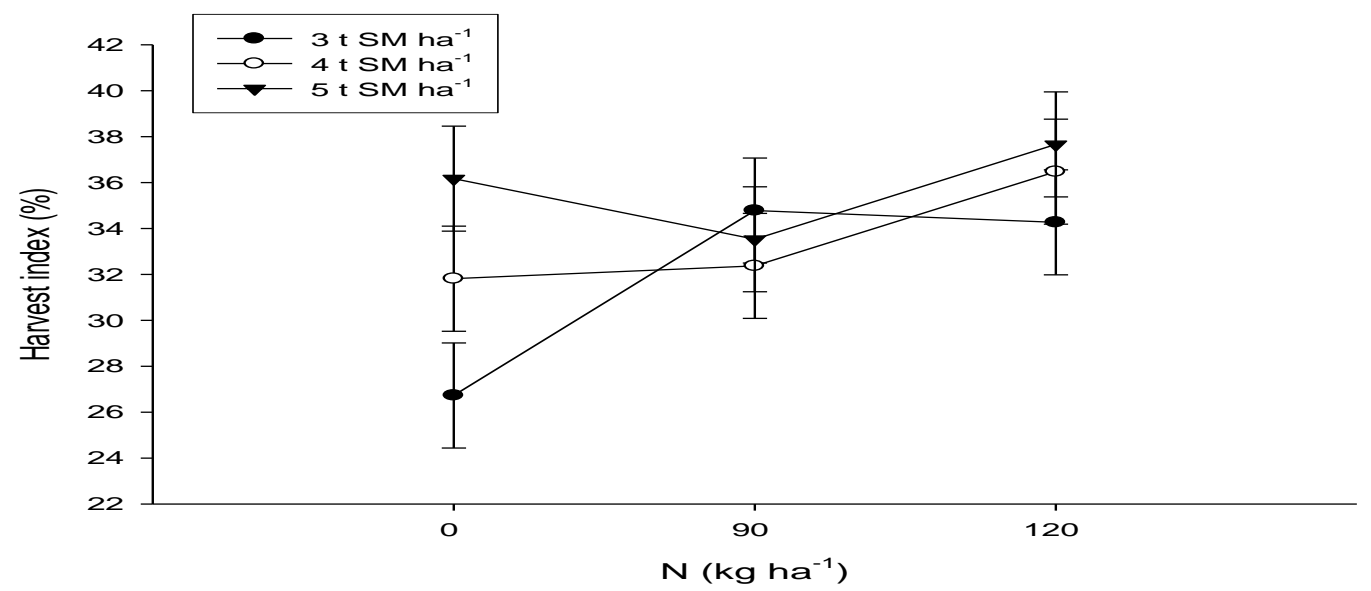

Figure 12. Interactive response of sheep manure (SM) and nitrogen $(\mathrm{N})$ for harvest index $(\%)$

\section{Conclusion}

From the above results it is concluded that application of $5 \mathrm{t}$ sheep manure $\mathrm{ha}^{-1}$ at 15 days before sowing and $120 \mathrm{~kg} \mathrm{~N}^{-1}$ produce more dry matter accumulation in terms of leaves, stem, cobs and grains. Hence, it is recommended for higher dry matter returns in maize crop.

\section{Authors' contributions}

Conceived and designed the experiments: $S$ Khan, A Khan \& F Jalal, Performed the experiments: S Khan, M Khan \& H Khan, Analyzed the data: A Khan \& F Jalal, Contributed reagents/ materials/ analysis tools: A Khan, F Jalal, S Badshah \& S Shah, Wrote the paper: S Khan, A Khan \& F Jalal.

\section{References}

1. Tagne A, Feujio \& Sonna C (2008). Essential oil and plant extracts as potential substitutes to synthetic fungicides in the control of fungi. International Conference Diversifying crop protection, Oct La Grande-Motte, Franc12-15 e.

2. Farhad, W, Saleem MF, Cheema MA \& Hammad HM (2009). Effect of poultry manure levels on the productivity of spring maize. J Animal Plant Sci 19(3): 122-125.

3. Oad FC, Buriro UA \& Agha SK (2004). Effect of organic and inorganic fertilizer application on maize fodder production. Asian J Plant Sci 3(3): 375-377.
4. Tanaka A \& Yamaguchi J (1972). Dry matter production, Yield components and grain of the maize plant: Hokkaido University.

5. Iqbal A, Iqbal MA, Raza A, Akbar N, Abbas RN \& Khan HZ (2014). Integrated nitrogen management studies in forage maize. Ameri. Eura. J Agric \& Envi Sci 14(8): 744-747.

6. Ibeawuchi II, Opara FA, Tom CT \& Obiefuna JC (2007). Graded replacement of inorganic fertilizer with organic manure for sustainable maize production in Owerri Imo State, Nigeria. Life Sci J 4(2): 82-87.

7. Amin ME (2011). Effect of different nitrogen sources on growth, yield and quality of fodder maize (Zea mays L.) $J$ Saudi Soc Agri Sci 10: 17-23.

8. Warriach EA, Ahmad N, Basra SM, \& Afzal L (2002). Effect of nitrogen on source sink relationship in wheat. Int $J$ Agri Bio 4:300-302.

9. Gasim S (2001). Effect of nitrogen, phosphorus and seed rate on growth, yield and quality of forage maize (Zea mays L), M.Sc. Thesis, Faculty of Agric., Univ. of Khartoum.

10. Hocking $\mathrm{P}$, Kirkegaard J, AngusJ, GibsonA \& Koetz E (1997). Comparison of canola, Indian mustard and linola in two contrasting environment. I. Effects of nitrogen fertilizer on dry matter production, 
seed yield and seed quality. Field Crops Research 49: 107-125.

11. Plaut Z, Butow B, Blumenthal C \& Wrigley C (2004). Transport of dry matter into developing wheat kernels and its contribution to grain yield under post anthesis water deficit and elevated temperature, Field Crop Res 86: 185198.

12. Havlin JL, Tisdale SL, Nelson WL \& Beaton JD (2005). Soil fertility and fertilizers: An introduction to nutrient management. Pearson Education, incorporation upper Saddle River, New Jersey.

13. Ogola JBO, Wheeler TR \& Harris PM. (2002). Effects of nitrogen and irrigation on water use of maize crops. Field Crop Res 78: 105-117.

14. Habtegebrial K, Singh BR \& Haile M (2007). Impact of tillage and nitrogen fertilization on yield, nitrogen use efficiency of eragrostis, trotter and soil properties. Soil Till. Res 94: 55- 63.

15. Ali S, Uddin S, Ullah O, Shah S, Din SU, Ali T \& Din IU (2012). Yield and yield components of maize response to compost and fertilizer-nitrogen. Food Sci. Qual. Manag 38: 39-44.

16. Rautaray SK, Ghosh BC \& Mittra BN (2003). Effect of fly ash, organic wastes and chemical fertilizers on yield, nutrient uptake, heavy metal content and residual fertility in a ricemustard cropping sequence under acid lateritic soils. Bioresource Technol 90: 275-283.

17. Satyajeet RK, Nanwal \& Yadav VK (2007). Effect of integrated nutrient management in nitrogen, phosphorus and potassium concentration, uptake and productivity in pearl millet. $J$ Maharastra Agri. Universities 32: 186188.

18. Ghosh P, Bandyopadhyay K, Manna M, Mandal K, Misra A \& Hati K (2004). Comparative effectiveness of cattle manure, poultry manure, phospho compost and fertilizer NPK on three cropping system in vertisols of semi-arid tropics II. Dry matter yield, nodulation, chlorophyll content and enzyme activity. Biores Tech 95: 8593.

19. Dekisissa T, ShortI \& Allen J (2008). Effect of soil amendment with compost on growth and water use efficiencyof amarannath. In: Proc. of UCOWR/NIWR Annual Conf. Int'l. Water Resources: Challenges for the $21^{\text {st }}$ Century and Water Res. Edu: 2224, Durham, NC.

20. Shadanpour F, Mohammadi TA \& Hashemi MK (2011). The effect of cow manure vermicompostas the planting medium on the growth of marigold. Annals Biol. Res 2(6): 109-115.

21. Xie R \& Mackenzie A (1986). Urea and manure effects on soil nitrogen and corn dry matter yield. Soil Science Soci of Amer J 50: 1504-1509.

22. Khan M, Abid AM, Hussain N \& Masood MU (2005). Effect of phosphorous levels on growth and yield of maize cultivars under saline conditions. Int J Agric Biol (3): 511514.

23. Elhindi K (2012). Evaluation of composted green waste fertigation through surface and sub surface drip irrigation systems on pot marigold plants (Calendula officinalis

L.) grown on sandy soil. Aus J Crop Sci 6(8): 1249-1259.

24. Thulasizwe SM \& Simeon AM (2013). Influence of kraal manure application time on emergence, growth and grain yield of maize grown in two soils with contrasting textures. J Food Agri Env 11(1): 422-427.

25. Baiyeri KP \& Tenkouano A (2008). Manure placement effects on root and shoot growth and nutrient uptake of 'PITA 14' Plantain hybrid (Musa sp.Aaab). Africa J Agric Res 3(1): 1321.

26. Ayeni LS \& Adetunji MT (2010).Integrated application of poultry manure and mineral fertilizer on soil chemical properties, nutrient 
uptake, yield and growth components of maize. Nature Sci J 8(1): 60-67.

27. Amanullah MM, Yasin MM, Somasundaram E, Vaiypapuri K, Sathyamoorthi K \& Pazhanivelan S (2006). N availability in fresh and composted poultry manure. Res J Agric Bio Sci 2(6): 406-412.

28. Desta HA (2015). Response of maize (Zea mays L.) to different levels of nitrogen and sulfur fertilizers in Chilga District, Amhara National Regional State, Ethiopia. Basic Res J Soil Env Sci 3(3): 38-49.

29. Schroder JJ, Neeteson JJ, Oenema O \& Struik PC (2000). Does the crop or the soil indicate how to save nitrogen in maize production. Reviewing the state of the art. Field Crops Res 66:151-164.

30. Akongwubel AO, Ewa UB, Prince A, Jude O, Martins A, Simon O \& Nicholas O (2012). Evaluation of agronomic performance of maize (Zea mays L.) under different rates of poultry manure application in an Ultisol of Obubra, cross river state, Nigeria. Int J Agric Forest 2(4): 138144.

31. Nyle C \& Brady R (2003). Nature and properties of soil. 13th edition, New York:960.

32. Dauda SN, Ajayi FA, \& Ndor E (2008).Growth and yield of water melon (Citrullus lanatus) as affected by poultry manure application. J Agric Soc Sci 4: 121-124.

33. Buriro $M$, Oad A, Nangraj $T \&$ Gandahi AW (2014). Maize fodder yield and nitrogen uptake as influenced by farm yard manure and nitrogen rates. European Acad Res 2(9): 1162411637.

34. Quansah GW (2010). Effect of organic and inorganic fertilizers and their combinations on the growth and yield of maize in the semi-deciduous forest zone of Ghana. Bsc (hons) thesis: department of crop and soil sciences, university of science and technology, kumasi, Ghana.

35. Nasim, W, Ahmad A, Khaliq T, Wajid A, Munis MFH, Chaudhry HJ, Maqbool MM, Ahmad S \& Hammad HM (2012).Effect of organic and inorganic fertilizer on maize hybrids under agro-environmental conditions of Faisalabad-Pakistan. African J Agri Res 7(17): 2713-2719.

36. Khaliq T, Mahmood T, Kamal J \& Masood A (2004). Effectiveness of farmyard manure, poultry manure and nitrogen for corn (Zea mays L.) productivity. Int J Agri Biol 6(2): 6063.

37. Uzoma $\mathrm{KC}$, Inoue $\mathrm{M}$, Andry $\mathrm{H}$, Fujimaki H, Zahoor A \& Nihihara E (2011). Effect of cow manure biochar onmaize productivity under sandy soil condition. Soil Use \& Mgt 27: 205212.

38. Liu X, Herbert SJ, Jin J, Zhang Q \& Wang G (2004). Responses of photosynthetic rates and yield/quality of main crops to irrigation and manure application in the black soil area of Northeast Chin. Plant and Soil 261(1): 55-60.

39. Smaling EMA, Nandwa SM, Prestle H, Roetter H \& Muchena FN (2002). Yield response of maize to fertilizers and manure under different agroecological conditions in Kenya, Elsevier Dordrecht, Netherlands 41: 241-252.

40. Hokmalipour S \& Darbandi $\mathrm{MH}$ (2011).Investigation of nitrogen fertilizer levels on dry matter remobilization of some varieties of corn (Zea maysL). World Appl Sci J 12(6): 862-870.

41. Mohsin AU, Ahmad J, Ahmad AUH, Ikram RM \& Mubeen K (2012). Effect of nitrogen application through different combinations of urea and farm yard manure on the performance of spring maize (Zea mays L.). $J$ Animal Plant Sci 22(1): 195-198. 